\title{
WHAT CAN THE EUROPEAN UNION EXPECT FROM THE APPLICATION OF THE FINAL BASEL III GUIDELINES?
}

\author{
László Seregdi
}

\begin{abstract}
In December 2017, the Basel Committee on Banking Supervision amended several points of its Basel III guidelines published earlier. The amended version was published under the name Basel III finalization. The amendments limit the internal model based capital requirement calculation methods, make credit and market risk methods more risk-sensitive, standardise the calculation methods of the operational risk capital requirement and raise the leverage ratio requirement for Global Systemically Important Institutions (G-SIIs). The European Banking Authority examined how the aforementioned amendments would affect European banks and put forward suggestions as to how these amendments should be transposed into EU law. Taking into account these data and recommendations, the European Commission is to start drawing up its proposals on the amendment of EU laws, primarily the CRD and the CRR.
\end{abstract}

JEL codes: $\mathrm{G}_{21}, \mathrm{G} 28, \mathrm{~L} 51, \mathrm{~N}_{24}, \mathrm{O}_{16}$

Keywords: banking regulation, EBA, capital requirements

\section{INTRODUCTION}

The Basel Committee on Banking Supervision has been publishing professional recommendations since 1975 in order to standardise the prudential requirements and methods of banking supervision applying to banks in individual countries, thus influencing the regulatory and supervisory environment of the financial sector at global level. Although the compliance with the recommendations of the Basel Committee (Committee) is not compulsory and the Committee is not entitled to impose any sanctions in the case of non-compliance with its recommen-

1 László Seregdi is a Supervisory Advisor at the Regulation Department of the National Bank of Hungary. Email: seregdil@mnb.hu. 
dations, all countries with a developed financial system strive to comply with the recommendations of the Committee in practice.

The Committee published its recommendation in July 1988 known as Basel Capital Accord (or Basel I), which included the method of calculation of solvency capital and the risk-weighted balance sheet total, as well as the capital adequacy ratio of $\min .8 \%$. Over time, these methods have been continuously expanded. In 1996, they were amended by the market risk capital requirements. In 2004, Basel II introduced other significant changes, including, inter alia, the introduction of the operational risk capital requirement, the definition of the elements of the supervisory review process and the approval of the use of internal models for the calculation of capital requirement. As the global financial crisis pointed out the deficiencies of the previously somewhat permissive and lax system of requirements, the Committee had to impose restrictions in 2010, primarily to tighten the rules of considering the elements of capital and increase capital requirements (Basel III). The Committee also aimed to review its entire recommendation. The result of this review was the document called Basel III finalization (BCBS, 2017), published in December 2017.

\section{THE MAIN ELEMENTS OF THE BASEL III FINALIZATION}

The finalization of the Basel III recommendation was preceded by long professional consultations and preliminary impact studies. By carrying out the amendments, the main goal of the Committee was to decrease the volatility of riskweighted assets value, thus making the specification of capital requirements more reliable. The amendments can be divided into six main thematic categories, including the introduction of the output floor, the transformation of the system of credit, market and operational risk capital requirement calculation, fine-tuning of the method applied to CVA risk and raising the leverage ratio requirement for Global Systemically Important Financial Institutions.

\subsection{Output floor}

In the course of approving of the usability of internal models for capital requirement calculation, in 2004, the Committee introduced a threshold value system, which was originally meant to be temporary, so that in the case of credit risk or operational risk, the capital requirement of banks applying the internal model could not become lower than 95,90 and $80 \%$ of the capital requirement calculated based on Basel I within three years following the introduction (2006-2008), thus limiting the capital requirement reductions achievable by using the internal mod- 
el. In spite of the fact that this capital requirement limit remained in force in EU legislation for a longer period (first, it was extended by 2009, 2011, then finally by the end of 2017 (European Commission, 2013), currently, neither the EU regulations, nor the Basel recommendations contain such a limit. The new output floor is to be introduced gradually as of 2022, in accordance with the following table.

Table 1

The gradual introduction of the output floor

\begin{tabular}{lcccccc}
\hline Date & $\mathbf{2 0 2 2}$ & $\mathbf{2 0 2 3}$ & $\mathbf{2 0 2 4}$ & $\mathbf{2 0 2 5}$ & $\mathbf{2 0 2 6}$ & $\mathbf{2 0 2 7}$ \\
Output floor & $50 \%$ & $55 \%$ & $60 \%$ & $65 \%$ & $70 \%$ & $72.5 \%$ \\
\hline
\end{tabular}

Source: Committee

The main reason for the introduction of the output floor is that based on the Committee's experience, the results of the banks' internal models significantly differ. Some of these differences are attributable to the differences between the portfolios of banks and their business models, however, there is no substantive reason for a significant part of the differences. Furthermore, in the event of a crisis, the results of internal models are very volatile. Along with growing probability of default (PD) values, the capital requirement is increasing rapidly, which strengthens procyclical effect. Consequently, the aim of the capital requirement limit is to stabilise the results of internal models and prevent excessive derogations from the results calculated by means of the standard approaches.

\subsection{Calculation of the credit risk capital requirement}

At the end of 2017, the Committee significantly transformed capital requirement calculation based on both the credit risk standardised approach and the internal model. The main principle of the transformation of the standardised approach was that it should be more risk-sensitive and suitable for the use of IRB as output floor. The Committee tried to encourage banks to rely less on the ratings provided by external credit rating agencies in the course of applying the standardised approach. As a result of the revision, the risk weights on shares, subordinated loan capital and exposures to banks will become stricter. The risk weights of loans secured by real estate property, which shall be specified based on whether the loan is secured by a residential or commercial real estate property, whether the source of repayment is the income arising from the property and the amount of LTV (loan-to-value), are also to be transformed considerably. 
Table 2

Risk weights of exposures covered by real property

\begin{tabular}{|c|c|c|c|c|c|c|c|c|}
\hline \multicolumn{9}{|c|}{ Exposures covered by residential property } \\
\hline LTV ratio & $\begin{array}{c}\text { under } \\
50 \%\end{array}$ & $\begin{array}{c}50 \%- \\
60 \% \\
\end{array}$ & $\begin{array}{c}60 \%- \\
70 \% \\
\end{array}$ & $\begin{array}{c}70 \%- \\
80 \%\end{array}$ & $\begin{array}{c}80 \%- \\
90 \% \\
\end{array}$ & $\begin{array}{l}90 \%- \\
100 \%\end{array}$ & $\begin{array}{c}\text { over } \\
100 \%\end{array}$ & $\begin{array}{c}\text { It does not meet } \\
\text { the criteria }\end{array}$ \\
\hline \multicolumn{9}{|c|}{ Residential real estate exposures in general } \\
\hline Total credit RW & $20 \%$ & $25 \%$ & \multicolumn{2}{|c|}{$30 \%$} & $40 \%$ & $50 \%$ & $70 \%$ & $\begin{array}{l}\text { Risk weight } \\
\text { of the Client }\end{array}$ \\
\hline $\begin{array}{l}\text { Credit sharing } \\
\text { RW }\end{array}$ & \multicolumn{2}{|c|}{$20 \%$} & \multicolumn{5}{|c|}{ Risk weight of the Client } & $\begin{array}{l}\text { Risk weight } \\
\text { of the Client }\end{array}$ \\
\hline \multicolumn{9}{|c|}{ Income-producing residential real estate exposures (IPRRE) } \\
\hline Total credit RW & $30 \%$ & $35 \%$ & \multicolumn{2}{|c|}{$45 \%$} & $60 \%$ & $75 \%$ & $105 \%$ & $150 \%$ \\
\hline \multicolumn{9}{|c|}{ Commercial real estate exposures (CRE) } \\
\hline \multicolumn{9}{|c|}{ Commercial real estate exposures in general } \\
\hline \multirow[b]{2}{*}{ Total loan } & \multicolumn{2}{|c|}{$\mathrm{LTV} \leq 60 \%$} & \multicolumn{5}{|c|}{ LTV $>60 \%$} & $\begin{array}{l}\text { It does not meet } \\
\text { the criteria }\end{array}$ \\
\hline & \multicolumn{2}{|c|}{$\begin{array}{l}\text { Min. }(60 \%, \\
\text { the risk weight } \\
\text { of the Client) }\end{array}$} & \multicolumn{5}{|c|}{ Risk weight of the Client } & $\begin{array}{l}\text { Risk weight } \\
\text { of the Client }\end{array}$ \\
\hline \multirow[b]{2}{*}{ Credit sharing } & $\mathrm{LTV} \leq$ & & \multicolumn{5}{|c|}{$\mathrm{LTV}>55 \%$} & $\begin{array}{l}\text { It does not meet } \\
\text { the criteria }\end{array}$ \\
\hline & \multicolumn{2}{|c|}{$\begin{array}{l}\text { Min. }(60 \% \text {, } \\
\text { the risk weight } \\
\text { of the Client) }\end{array}$} & \multicolumn{5}{|c|}{ Risk weight of the Client } & $\begin{array}{l}\text { Risk weight } \\
\text { of the Client }\end{array}$ \\
\hline \multicolumn{9}{|c|}{ Income-producing commercial real estate exposures (IPCRE) } \\
\hline \multirow[t]{2}{*}{ Total loan } & \multicolumn{2}{|c|}{$\mathrm{LTV} \leq 60 \%$} & \multicolumn{2}{|c|}{$\begin{array}{c}60 \%<\mathrm{LTV} \\
\leq 80 \%\end{array}$} & \multicolumn{3}{|c|}{ LTV $>80 \%$} & $\begin{array}{l}\text { It does not meet } \\
\text { the criteria }\end{array}$ \\
\hline & \multicolumn{2}{|c|}{$70 \%$} & \multicolumn{2}{|c|}{$90 \%$} & \multicolumn{3}{|c|}{$110 \%$} & $150 \%$ \\
\hline \multicolumn{9}{|c|}{ Land acquisition, Development, and Construction (ADC) exposures } \\
\hline $\begin{array}{l}\text { Exposure to } \\
\text { companies / SPV }\end{array}$ & \multicolumn{8}{|c|}{$150 \%$} \\
\hline $\begin{array}{l}\text { Covered by } \\
\text { pre-contractual } \\
\text { agreements }\end{array}$ & \multicolumn{8}{|c|}{$100 \%$} \\
\hline
\end{tabular}

Source: EBA, Basel Committee

The main reason for the changes of developed methods to credit risks is that the differences arising from IRB approaches have to be reduced, as the IRB approaches have become too complex and non-transparent. The audits and tests expressly dealing with this problem also indicated that the results significantly varied from one bank to another if the individual institutions calculated the capital requirement of the same portfolio by means of their internal models. The major elements of the changes related to the use of the IRB approach include that the developed 
IRB approach shall not be used in the case of exposures to banks and large companies. The basic IRB approach or the standardised approach shall be used instead. In the case of equity exposures, only the standardised approach shall be used, and the requirements will introduce new or increased minimum PD, LGD and CCF (input floor) values.

\subsection{Market risk capital requirement}

Market risk is a special topic in the sense that the Committee specified the relevant Basel requirements, which were meant to be final, in January 2019 instead of 2017 (BCBS, 2019). These amendments primarily aimed to make the market risk standardised approach more risk-sensitive, taking into account sensitivity-based calculations related to the individual risk classes. In the framework of the amendments, a simplified method is to be introduced for institutions with a small trading book and the risk weights are to be redefined in terms of the general interest rate and the foreign exchange rate risk.

\subsection{Operational risk}

A key element of the new capital requirement calculation system of operational risk is that capital requirement shall not be calculated by means of the advanced measurement approach (AMA) based on the institutions' own systems anymore. Instead of the different approaches applied so far, there will be a standardised approach based on two assumptions: (i) the operational risk depends on the size of the bank, (ii) if a bank had high losses arising from operational risk in the past, they are expected to be high in the future, as well. In view of the above, the capital requirement will be product of the relevant indicator based on the revenue (BI Business Indicator) and the loss correction ((ILM - Internal Loss Multiplier). It will not be compulsory for smaller banks (under a Business Indicator of EUR 1 billion) to apply the correction factor that larger banks had to calculate based on the data of the loss arising from operational risk over the past ten years.

\subsection{CVA risk}

Credit value assessment (CVA) adjusts the mid-market valuation of the portfolio of outstanding transactions with clients. This adjustment reflects the current market value of the credit risk of the counterparty to the institution, but does not reflect the current market value of the credit risk of the institution to the counterparty. CVA risk is the risk of potential loss arising from the change in the value of 
CVA due to the change in the partner's credit risk or market factors calculated on the basis of derivative exposures. The final Basel III recommendation introduced new CVA capital requirement calculation methods which also depend on the size of the bank, putting an end to the possibility of calculating the capital requirement of the CVA risk based on the internal model and harmonising the approaches used for the calculation of the CVA and the market risk capital requirement.

\subsection{G-SII increased leverage ratio}

The Basel III guidelines introduced the minimum leverage ratio requirement amounting to $3 \%$ of the core $\left(\mathrm{T}_{1}\right)$ capital. However, the Committee intended to further tighten this requirement in the case of Globally Systemically Important Institutions (G-SII). As a priori stricter capital adequacy requirements apply to G-SIIs due to the capital buffer system, the Committee is on the opinion that the regulation of the leverage ratio should reflect this increased requirement level, as well. Consequently, the leverage ratio requirement of G-SIIs shall increase by $50 \%$ of the capital buffer calculated for such institutions (in other words, if a bank's G-SII capital buffer requirement is $1 \%$, its minimum leverage ratio requirement shall be $3.5 \%$ instead of $3 \%$ ). Interestingly, this is the only element of the final Basel III recommendation that can also be found in the already adopted CRR2 rules, which shall enter into force as of June 2021. Moreover, the CRR2 obliges the European Commission to examine by December 2020 whether it would be reasonable to extend this requirement to other systemically important institutions.

\section{EBA IMPACT STUDY}

Prior to the amendment of the Basel III recommendation, the Committee conducted several impact studies, the results of which predicted that the effects of the amendments could be fairly significant in the case of certain banks. In May 2018, the European Commission requested the European Banking Authority (EBA) to conduct an impact study to examine the expected impacts of the full implementation of the final Basel III recommendation in the EU and make proposals regarding any reasonable derogations from the final Basel III recommendation due to the characteristics of the EU's banking system in the course of implementation.

In order to perform this task, the EBA started collecting very detailed data, including, on the one hand, numerical data, on the other hand, qualitative information which complemented the conclusions drawn based on the quantitative data. The EBA requested altogether 189 banks from 19 EU Member States to complete questionnaires. 104 of them belonged to the category of large banks (including 
8 G-SIIs and 67 other systemically important institutions - O-SIIs and 29 large banks), 61 were medium-sized and 24 small institutions. Based on the above, it can be stated that such banks constituted a fairly high percentage of the EU's banking system. With regard to the fact that only one Hungarian bank took part in the survey, the analysis does not contain special Hungarian data, however, the overall results also include domestic figures. In the case of EU Member States from which at least three banks were involved in the impact study, the results were published in terms of the country-specific impacts, as well.

In the end, the EBA published the expected effects in August 2019 (EBA, 2019) and the documents containing its proposals regarding the way of implementation of the Basel recommendation.

The major conclusions drawn on the basis of the analysis of the numerical data are summarised in the following two tables:

Table 3

The estimated impact expressed in percentage of the core capital minimum requirement in the case of the full implementation of Basel III

\section{Impact expressed in percentage}

\begin{tabular}{|c|c|c|c|c|c|c|c|c|c|c|}
\hline $\begin{array}{l}\text { The size of } \\
\text { the bank }\end{array}$ & $\Delta \mathrm{SA}$ & $\Delta \mathrm{IRB}$ & $\Delta \mathrm{CCP}$ & $\Delta \mathrm{SEC}$ & $\Delta \mathrm{MKT}$ & $\Delta \mathrm{OP}$ & $\Delta \mathrm{CVA}$ & $\Delta \mathrm{LR}$ & $\Delta \mathrm{OF}$ & $\Delta$ Total \\
\hline $\begin{array}{l}\text { Banks in } \\
\text { total }\end{array}$ & 2.7 & 2.7 & 0.1 & 0.6 & 2.5 & 3.3 & 3.9 & -0.5 & 9.1 & 24.4 \\
\hline Large banks & 2.3 & 2.8 & 0.1 & 0.7 & 2.6 & 3.4 & 4.1 & -0.5 & 9.5 & 25.0 \\
\hline $\begin{array}{l}\text { out of these } \\
\text { G-SII }\end{array}$ & 1.7 & 3.5 & -0.1 & 1.2 & 4.2 & 5.5 & 5.1 & 0.0 & 7.6 & 28.6 \\
\hline $\begin{array}{l}\text { out of these } \\
\text { O-SII }\end{array}$ & 2.3 & 1.7 & 0.2 & 0.3 & 1.6 & 2.1 & 3.7 & -0.5 & 12.1 & 23.6 \\
\hline $\begin{array}{l}\text { Medium- } \\
\text { sized banks }\end{array}$ & 9.7 & 0.1 & 0.0 & 0.0 & 0.9 & 0.3 & 0.5 & -1.1 & 0.9 & 11.3 \\
\hline Small banks & 10.7 & 0.0 & 0.2 & -1.9 & 0.0 & -3.7 & 0.3 & -0.1 & 0.0 & 5.5 \\
\hline
\end{tabular}

Notes: SA - credit risk standardised approach; IRB - advanced internal ratings-based approach to credit risk; CCP - central counterparty clearing house; SEC - securitisation; MKT - market risk; OP - operational risk; CVA - credit value assessment; LR - leverage ratio; OF - output floor.

Source: EBA, Basel III Reforms: Impact Study and Key Recommendations (2019) 
Table 4

Capital adequacy ratios and capital shortages by bank size

\begin{tabular}{|c|c|c|c|c|c|c|c|c|c|}
\hline \multirow[b]{2}{*}{$\begin{array}{l}\text { The size } \\
\text { of the bank }\end{array}$} & \multicolumn{3}{|c|}{$\begin{array}{c}\text { Common Equity Tier } \\
1 \text { (CET1) }\end{array}$} & \multicolumn{3}{|c|}{$\begin{array}{l}\text { Tier } 1 \text { Capital } \\
\text { (T1) }\end{array}$} & \multicolumn{3}{|c|}{ Total capital } \\
\hline & 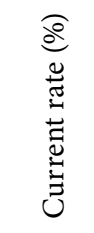 & 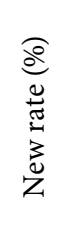 & 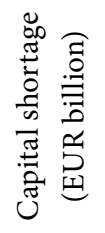 & 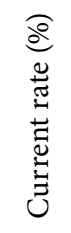 & 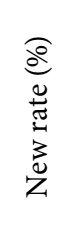 & 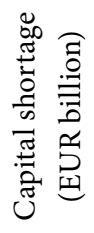 & 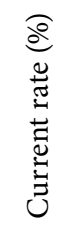 & 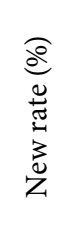 & 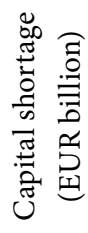 \\
\hline Banks in total & 14.4 & 11.5 & 91.1 & 15.3 & 12.3 & 127.5 & 17.9 & 14.3 & 135.1 \\
\hline Large banks & 14.2 & 11.4 & 91.0 & 15.2 & 12.2 & 126.8 & 17.8 & 14.2 & 134.1 \\
\hline out of these G-SII & 12.7 & 9.9 & 53.5 & 13.8 & 10.8 & 69.0 & 16.2 & 12.7 & 82.8 \\
\hline out of these O-SII & 15.4 & 12.5 & 33.6 & 16.3 & 13.2 & 51.5 & 19.2 & 15.6 & 43.8 \\
\hline $\begin{array}{l}\text { Medium-sized } \\
\text { banks }\end{array}$ & 17.4 & 15.2 & 0.1 & 17.6 & 15.4 & 0.8 & 19.0 & 16.6 & 0.9 \\
\hline Small banks & 17.0 & 16.0 & 0.0 & 17.2 & 16.1 & 0.0 & 18.3 & 17.1 & 0.1 \\
\hline
\end{tabular}

Source: EBA, Basel III Reforms: Impact Study and Key Recommendations (2019)

Based on the data above, the following main conclusions can be drawn:

- If the Basel III finalization were fully transposed into the EU legislation, the Tier 1 capital requirement of European banks would increase by $24.4 \%$. In particular, the increase in the capital requirement of G-SIIs (28.6\%) and O-SIIs (23.6\%) would be significant.

- In the case of G-SII banks, the capital requirement growth would be primarily attributable to the changes in the advanced internal ratings-based approach, market risk, operational risk, CVA risk and the output floor regulation.

- Regarding O-SII banks, the situation is similar, however, in that case, the introduction of the output floor has an especially significant effect.

- In the case of small and medium-sized banks, only changes to the credit risk standardised approach increase the Tier 1 capital (as these banks use the standardised approach for calculating the capital requirement in the first place).

- As for small banks, due to the standardisation of the rules for the calculation of operational risk capital requirement, the Tier 1 capital requirement is rather decreasing than increasing. 
- Due to changes in the calculation methods of the leverage ratio, the Tier 1 capital requirement is decreasing in the case of each bank type, except for GSII banks. Nor can any increase be observed in the case G-SII banks.

- If the Basel III recommendation were fully implemented, EU banks would have a Tier 1 capital shortage of altogether EUR 135.1 billion. In other words, they would need a capital increase of at least the aforementioned amount if they wanted to reach the minimum capital requirements. This shortage affects only large banks. In the case of small and medium-sized banks, the shortage of Tier 1 capital is insignificant.

In its detailed impact study, the EBA added further detailed information to its main statements. The most important pieces of information are the following:

- Currently, the total capital adequacy ratio of the banks in the sample is $17.9 \%$. If the Basel III recommendation were fully implemented, this value would fall to $14.3 \%$.

- The composition of the capital requirement increase is in line with the original intention of the regulator according to which riskier activities should have higher capital requirement. In view of the above, such increases in capital requirement are changes which reflect the original intention of the regulator and increase the safety of the EU's banking system (e.g. higher risk weight of shares, restriction of the use of internal models).

- In the case of the credit risk standardised approach, the changes mainly affect small and medium-sized banks. The increase in Tier 1 capital is the result of the growth of the risk weights of shares, subordinated loan capital and exposures to banks.

- Regarding banks applying the advanced approach (IRB) for the calculation of credit risk capital requirement, the increase in capital requirement is primarily caused by the restriction of the use of the advanced methods. Owing to the restriction of the use of advanced approaches, these banks are forced to calculate by means of less developed methods, which results in higher capital requirement. In the case of 40 banks out of the 79 banks using the IRB in the sample, the change is so significant that it even leads to capital shortage, therefore these banks have to be prepared to fill the gap by involving new capital or building internal capital. Although the EBA impact study does not include any detailed Hungarian data, it should be mentioned that the impact of the output floor on Hungarian banks is only indirect (it rather affects foreign parent banks only), as due to high domestic default data from the past, the advanced approaches usually lead to a higher capital requirement than the standard method. 
- In the case of the CVA risk, the main reason for the growth is that currently, derogating from the Basel recommendation, the EU's own regulation, namely Article 382 of the CRR, exempts several exposures from CVA risk capital requirement calculation (e.g. transactions with non-financial contractual parties, intra-group transactions). If the Basel recommendation were fully adopted, such exemptions should be cancelled, which would result in capital requirement increase.

- As regards market risk capital requirements, the EBA suggests that the impact of the actual change in capital requirement should be re-examined based on the data from 2019, because the assessment of the impacts of the new Basel recommendation published in January 2019 would require the supply of new data.

- Concerning the increase in operational risk capital requirement, the impact is mainly caused by the introduction of the ILM value, therefore principally large banks are affected.

When interpreting the data and conclusions above, it should be taken into account that the planned date of the introduction of the final Basel III recommendation is 1 January 2022. Moreover, most rules are to be gradually introduced over a 5-year-long transitional period, which means that the final requirements shall be complied with only as of 2027. It is also very likely that the requirements will not be fully adopted during the implementation of the final Basel III recommendation by the EU, i.e. in the course of making the appropriate amendments to CRD and CRR. The EU will apply derogations justified by the characteristics of its banking system instead. Furthermore, due to the stricter criteria of the Basel III recommendation, the national supervisory authorities may change the capital requirements prescribed in the framework of 2nd pillar and the macroprudential supervisory authorities may reduce the already prescribed systemic risk buffers. The EBA impact study probably overestimates the market risk capital requirement, as it was already modified by the Committee's material in January 2019. When evaluating the results of the impact study, it should also be considered that it is based on static balance sheets. On the other hand, banks are expected to change their business strategies in order to reduce the amount of capital requirement and capital shortage. Consequently, the final impact could be much lower than the one predicted at the moment. Banks still have 8 years to raise the necessary capital.

At the request of the European Commission, the EBA also calculated the expected effects on the basis of an alternative scenario according to which the derogations from the Basel III recommendation already applied by the EU could continue 
to exist. Such derogations include in particular the preferential factor of 0.7619 applying to the exposures to small and medium-sized enterprises (SME factor), the exemptions from CVA risk and the disregard for bank-specific loss data (ILM factor) when calculating the operational risk capital requirement. Under the conditions above, the amount of the capital shortage revealed by the impact study would significantly decrease, as well (e.g. if the CVA exemptions remained, capital shortage would be only EUR 116.9 billion instead of EUR 135.1 billion).

\section{THE EBA'S RECOMMENDATIONS REGARDING THE IMPLEMENTATION OF THE FINAL BASEL III RECOMMENDATION BY THE EU}

The European Commission expressly requested the EBA to make recommendations on the way of the implementation of final Basel III recommendation by the EU based on the results of the assessment. Consequently, the EBA drew up detailed recommendations in the documents published. The most important recommendations were the following:

\subsection{General recommendations}

As a general recommendation, the EBA suggested that the main principle of the implementation of Basel III by the EU should be the full application of the recommendations specified in Basel III. Divergences should not be allowed unless they are indispensable. As far as compliance with the Basel III recommendation is concerned, the EU is not performing too well. In its audit conducted in 2014, the Committee found that the EU's regulation was materially non-compliant with the Basel III recommendation (BCBS, 2014). Neither do such divergences strengthen the credibility/reliability of the EU's banking system. Therefore, the EBA believes that it is important to reduce the number of divergences. The implementation of the final Basel III recommendation could be an appropriate occasion for this. At the same time, strengthening credibility more than offsets the advantages of capital requirement decrease gained from the use of divergences. According to the EBA, it is also important that the provisions of the final Basel III recommendation should be implemented by the EU according to the Basel implementation roadmap as of 2022 . 


\subsection{Recommendations related to credit risk}

A lot of points of the final Basel III recommendation allow even banks applying the standardised approach to reduce their dependence on external credit rating agencies and apply internal ratings instead. Namely, after the global financial crisis, several member states of the Committee took measures which restricted the usability of the ratings provided by external credit rating agencies in the standardised approach. However, the EBA recommends the European Commission to retain the use of the ratings of external credit rating agencies in its rules on the CRR standardised approach. The main reason for this is that the aforementioned procedure is the most suitable for ensuring a standard calculation method and equal conditions of competition.

Regarding the risk weighting of real estate exposures, there has been a major difference between the Basel rules and the EU rules so far in the sense that the CRR enabled the loan splitting of such exposures. In practice it meant that, if a part of the mortgage loan met the criteria of preferential risk weighting, it could be considered with a risk weight of $35 \%$, while the remaining part could be considered with the debtor's risk weight (in the case of a retail client: $75 \%$ ). At the same time, according to the procedure applied by the Basel recommendation, if a mortgage loan meets the criteria (e.g. it has an LTV value below $80 \%$ ), a risk weight of $35 \%$ shall be used. If it fails to meet the criteria, the whole exposure shall be weighted with a risk weight of $75 \%$. This major divergence will be less significant, as the final Basel III recommendation itself will allow the loan splitting of mortgage loans and the EBA also recommends the use of this new Basel procedure in the CRR.

It is very important that the EBA recommends the European Commission not to include more preferential factors for loans provided for small- and mediumsized enterprises and related to the financing of infrastructural investments in the EU regulations than that can be found in the Basel recommendation. One of the main differences between the Basel and the EU criteria has been the use of the SME factor (0.7619) so far. The final Basel III recommendation will introduce a risk weight of $0.85 \%$ for SME exposures, therefore according to the EBA, it is not necessary to retain the SME factor in the CRR anymore. On the other hand, the EBA believes that it is important to standardise the definition of SME so that the EU should not apply the option in the Basel III recommendation according to which the countries applying the recommendation could use an even more conservative SME definition. It is especially interesting that the EBA right away recommends the cancellation of the preferential risk factor of $0.75 \%$ (ISF) which supports infrastructural investments and has just been transposed in the CRR2. 
In its recommendations, the EBA suggests that the divergence from the Basel recommendations currently used in the CRR, applying to the exemption of shares within the group from deduction from the capital should be retained.

The EBA recommends the total implementation of the new Basel recommendations on counterparty risk exposures arising from securities financing transactions. At the same time, the EBA emphasises the need for further examinations prior to the enforcement of the minimum haircut floors specified in the Basel recommendation by the $\mathrm{EU}$.

\subsection{Recommendations related to operational risk}

Already in its earlier materials, the EBA was of the opinion that the appropriate incentives should be retained even after phasing-out the Advanced Measurement Approach (AMA) so that banks could reduce their losses arising from operational risk. In view of the above, the EBA supports that as many banks as possible should include the historic data of such losses in the calculation of the operational risk capital requirement. Therefore, the EBA recommended the European Commission that the use of the ILM factor, which is to be introduced by the final Basel III recommendation and has to be calculated based on the loss data from the past 10 years, should be compulsory for all medium-sized and large banks (belonging to the 2 nd and 3 rd categories. Moreover, even small banks should be allowed to take this factor into account, as in this way, credit institutions with the appropriate operational risk management procedures could decrease their capital requirement.

Pursuant to the final Basel III recommendation, in the course of collecting operational risk loss data, all loss data over EUR 20,00o should be considered. However, within national competence, it allows medium-sized and large banks to raise this threshold value to EUR 100,000. The EBA recommended the European Commission to include this possibility of national discretion in the CRR during the implementation of the Basel recommendations.

\subsection{CVA risk}

Currently, the EBA did not make a specific recommendation regarding CVA risk, but it recommended the European Commission to carry out further analyses prior to drawing up the EU laws on the calculation of the CVA risk capital requirement. 


\subsection{Output floor}

The EBA is clearly on the opinion that the output floor specified in the final Basel III recommendation shall be applied in the CRR, as well. However, regarding the development of specific rules, the EBA draws attention to the fact that the CRD contains capital buffer requirements which are not included in the Basel III recommendation (systemic risk and O-SII capital buffers). Consistent with reason, the final Basel III recommendation does not include any rules on such requirements. On the other hand, after long consultations, the EBA suggested that the output floor requirement should apply to these EU-specific capital buffers, as well. In practice, it means that the amount of the capital buffer should not be determined on the basis of the risk-weighted assets value calculated by means of the internal model, but it should also be adjusted by the output floor calculated by means of the standardised approach. In the case of banks where the output floor has a real restrictive effect, i.e. the capital requirement calculated on the basis of the internal model is lower than $72.5 \%$ of the capital requirement calculated by means of the standardised approach, this procedure will result in a higher capital buffer, as the capital buffer has to be calculated based on higher risk-weighted assets value adjusted by the output floor. The EBA recommends the consideration of the same risk-weighted assets value adjusted by the output floor for the calculation of the Pillar 2 capital requirement in the supervisory review process.

\section{FURTHER REQUEST FOR DATA AND PUBLIC CONSULTATION}

In view of the impact study conducted and implementation recommendations made by the EBA, the European Commission decided to request the EBA to conduct further investigations. In its recommendations, the EBA proposed that the European Commission shall enforce the output floor requirement at all levels of the consolidation. With regard to the fact that the use of the output floor is one of the most important factors of the capital requirement growth affecting European banks, the European Commission requested the EBA to illustrate the specific numerical effects the use of the output floor could have on all three levels (individual, sub-consolidated, consolidated) with detailed data. Furthermore, the European Commission also requests the EBA to examine the effects of the possible extension of the capital requirements to intra-group exposures in the case of shares and review how capital requirement calculation for such exposures could be made more risk-sensitive. The European Commission expects recommendations from the EBA regarding the improvement of the risk sensitivity of the ap- 
proaches applied in the case of specialized lending and requests the EBA to assess the expected rate of possible MREL shortfalls.

The EBA has already started the performance of the requested tasks. The questions are expected to be answered in the near future.

In addition, the European Commission announced a public consultation in the framework of which market participants will have the opportunity to send in their opinion about issues related to the implementation of the Basel III recommendation by the EU by 3 January $2020{ }^{2}$

\section{SUMMARY}

The EBA issued its impact study conducted at the request by the European Commission, as well as its recommendations regarding implementation in public documents of several hundreds of pages. The EBA is still working on some topics, in particular on the preparation of further impact assessments and recommendations related to the questions in the European Commission's latest request. The European Commission is conducting a public consultation on the most important questions regarding the implementation of the final Basel III recommendation by the EU. The drafting of the $\mathrm{CRR}_{3}$ and CRD6 legislative proposals shall start on the basis of this consultation later. The European Commission should definitely hurry with the preparation of the draft legislative amendments, as the preparation of legal texts, getting them through the appropriate decision-making bodies (the European Parliament and Council) and the provision of sufficient preparation all require a significant amount of time. The above-mentioned factors create doubts concerning the actual enforcement of these rules as of 1 January 2022 in the EU. The situation is only worsened by the circumstance under which the EBA should prepare draft implementing regulations, recommendations and opinions in 109 different topics owing to the amendments to the CRR2, CRD 5 and BRRD2, which is an extreme burden for both the EBA and the European Commission. However, it is a positive development that conducting the EBA impact study significantly facilitates the work of decision-making bodies, as on the basis of the study the numerical consequences of alternative decisions can be easily estimated.

2 Alignment EU rules on capital requirements to international standards (prudential requirements and market discipline), https:/ec.europa.eu/info/law/better-regulation/initiatives/finance2019-basel-3/public-consultation_en 


\section{REFERENCES}

BCBS (2014): Regulatory Consistency Assessment Programme (RCAP), Assessment of Basel III regulations - European Union. December, https://www.bis.org/bcbs/publ/d3oo.pdf.

BCBS (2017): Basel III: Finalising post-crisis reforms. December, https://www.bis.org/bcbs/publ/ d424.pdf.

BCBS (2019): Minimum capital requirements for market risk. January, https://www.bis.org/bcbs/ $\mathrm{publ} / \mathrm{d} 457 . \mathrm{pdf}$.

EBA (2019): EBA advises the European Commission on the implementation of the final Basel III framework. August, https://eba.europa.eu/eba-advises-the-european-commission-on-the-implementation-of-the-final-basel-iii-framework.

EC (2013): Capital Requirements - CRD IV/CRR - Frequently Asked Questions. https://ec.europa. eu/commission/presscorner/detail/en/MEMO_13_69o, July. 